Section Editor

John J. Millichap, MD

Mystery Case:

\title{
A 64-year-old woman with subacute encephalopathy
}

Figure $\quad$ MRI demonstrates bilateral mesiotemporal lobe enhancement in neurosyphilis

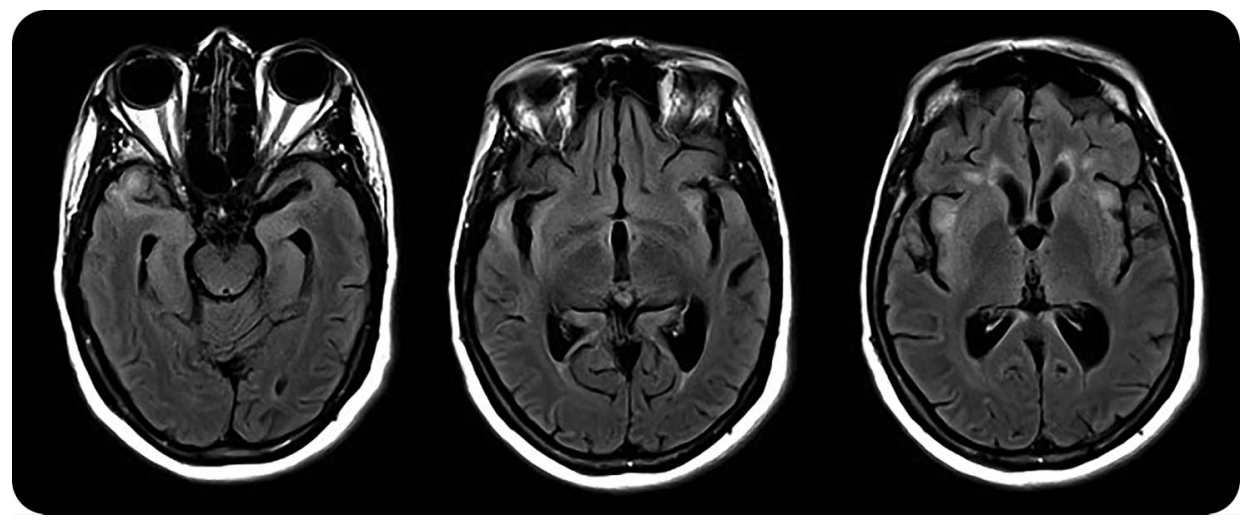

Axial brain MRI of a 64-year-old woman with bilateral multifocal white matter T2 signal abnormalities involving the mesiotemporal lobes, insular and subinsular regions, and external and extreme capsules. Pathologic gadolinium enhancement was not present.

A 64-year-old woman presented with progressive cognitive decline over 7 months. Her family noted a general slowing of her speech and thought process. She had developed a flat affect and difficulty with daily activities such as driving. There was no history of neurologic or psychiatric disorders.

On admission, the patient was alert and oriented to person, time, and place, but had hypophonic speech, impaired attention, and severely impaired short-term recall. Cranial nerves were normal, including reactive pupils bilaterally. Strength, sensation, and coordination were normal. Deep tendon reflexes were normal and symmetric. The gait was slow but not ataxic. The Romberg sign was not present.

An MRI demonstrated bilateral multifocal white matter T2 signal abnormalities involving the mesiotemporal lobes, insular and subinsular regions, and external and extreme capsules (figure). Spinal fluid analysis demonstrated elevated protein $(104 \mathrm{mg} / \mathrm{dL})$, pleocytosis (28 leukocytes $/ \mathrm{mm}^{3}$ with $88 \%$ lymphocytes), and a glucose level of $95 \mathrm{mg} / \mathrm{dL}$.

The differential diagnosis for the patient's subacute encephalopathy, in light of the imaging and CSF findings, included autoimmune/paraneoplastic (anti- $\mathrm{Hu}$, anti-NMDA, and anti-LGI1 antibodies) or infectious causes (herpes encephalitis). C-reactive protein and erythrocyte sedimentation rate were mildly elevated to $5.3 \mathrm{mg} / \mathrm{L}$ and $25 \mathrm{~mm} /$ hour, respectively. CSF Gram stain, culture, and CSF viral studies for varicella-zoster virus (VZV), herpes simplex virus, cytomegalovirus, and West Nile virus were negative. Serum HIV, Epstein-Barr virus, VZV, Lyme, thyroid peroxidase, and antinuclear antibodies, thyroid, renal, and liver function, and toxicology screen were unremarkable. CT of the patient's chest, abdomen, and pelvis was normal.

While the patient's syphilis and paraneoplastic laboratory panels were pending, the patient was treated empirically for a presumed inflammatory or autoimmune process with $1 \mathrm{~g}$ IV methylprednisolone daily for 5 days. She demonstrated improved memory, attention, and concentration.

Two days after the patient completed steroid therapy, the previously submitted serum treponemal immunoglobulin G returned positive and rapid plasma reagin was reactive at 1:64 dilution. In addition, the serum Treponema pallidum particle agglutination test and spinal fluid Venereal Disease Research Laboratory (VDRL) assays were positive (VDRL CSF titer 1:32). The patient received a 2-week course of IV penicillin G 4M units. At 1-month follow-up, her mental status had improved but moderate attention

From the Department of Neurology, Brigham and Women's Hospital, Harvard Medical School, Boston, MA.

Go to Neurology.org for full disclosures. Funding information and disclosures deemed relevant by the authors, if any, are provided at the end of the article. 
and memory deficits persisted. She did not have any clinical indications for reimaging.

DISCUSSION Typically, neurosyphilis presents with imaging findings consistent with ischemic lesions, cerebral atrophy, or cranial nerve sheath enlargement and neuropathies, most commonly cranial nerves VII and VIII. Other findings include leptomeningeal granulomas (gummata), leptomeningeal enhancement, white matter lesions, and arteritis. ${ }^{1,2}$ However, in this case, mesial temporal lobe hyperintensities on MRI have a broad differential that includes infections (such as herpes encephalitis), neoplastic disorders (such as gliomatosis or lymphoma), and autoimmune or paraneoplastic disorders (such as anti-Hu/ANNA1, anti-Ma, anti-VGKC, anti-NMDA receptor, or anti-GAD antibodies). Although diagnostic workup delayed recognition of neurosyphilis in this setting, ultimately the correct diagnosis was made. Because tertiary neurosyphilis has decreased incidence in the postpenicillin era and is often mimicked by other conditions, its diagnosis can be difficult and is often delayed. Furthermore, the spectrum of MRI abnormalities associated with neurosyphilis is not fully recognized and the findings often lack specificity. Mesiotemporal hyperintensity, as demonstrated in this case, has been previously recognized as an unusual imaging feature of neurosyphilis. ${ }^{3,4}$ Because neurosyphilis is considered the great imitator, from both a clinical and radiologic perspective, it is important for the clinician to maintain a high index of suspicion in the evaluation of a patient with subacute to chronic encephalopathy.

\section{STUDY FUNDING}

No targeted funding reported.

\section{DISCLOSURE}

The authors report no disclosures relevant to the manuscript. Go to Neurology.org for full disclosures.

\section{REFERENCES}

1. Bash S, Hathout GM, Cohen S. Mesiotemporal T2 weighted hyperintensity: neurosyphilis mimicking herpes encephalitis. AJNR Am J Neuroradiol 2001;22:314-316.

2. Fadil H, Gonzalez-Toledo E, Kelley BJ, Kelley RE. Neuroimaging findings in neurosyphilis. J Neuroimaging 2006; 16:286-289.

3. Abdelerahman KT, Santamaria DD, Rakocevic G. Pearls \& Oy-sters: neurosyphilis presenting as mesial temporal encephalitis. Neurology 2012;79:e206-e208.
4. Agayeva N, Karli-Oguz K, Saka E. Teaching NeuroImages: a neurosyphilis case presenting with atypical neuroradiologic findings. Neurology 2013;80:e119.

\section{MYSTERY CASE RESPONSES}

The Mystery Case series was initiated by the Neurology ${ }^{\circledR}$ Resident \& Fellow Section to develop the clinical reasoning skills of trainees. Residency programs, medical student preceptors, and individuals were invited to use this Mystery Case as an educational tool. Responses were solicited through a group e-mail sent to the American Academy of Neurology Consortium of Neurology Residents and Fellows and through social media.

All 21 responses we received came from individuals rather than groups. A total of $52 \%$ of respondents correctly described the MRI findings of this case, which included T2 hyperintensities primarily in the medial temporal lobes and insular and subinsular regions, as well as the external and extreme capsules. As for the differential diagnosis, $48 \%$ of respondents identified the importance of considering paraneoplastic and autoimmune etiologies given this limbic encephalitis-type presentation. A total of $33 \%$ of respondents mentioned herpes encephalitis in their differentials, but it is important to note that this would not be expected to present with a 7-month history, vs a chronic infectious etiology like neurosyphilis. A total of $14 \%$ of the respondents identified neurosyphilis as a possibility or considered testing for it in their proposed workup. The most complete answer in this regard came from Dr. Paloma Gonzalez-Perez at the University of Iowa, who also correctly noted that mesiotemporal hyperintensity has been previously reported with neurosyphilis. ${ }^{3,4}$

This case highlights the importance of considering neurosyphilis in the differential diagnosis for a subacute encephalopathy - in addition to neoplastic, autoimmune, paraneoplastic, and metabolic disorders - and demonstrates that one cannot rely on neuroimaging findings alone in these cases.

Aravind Ganesh, MD

Department of Clinical Neurosciences, University of Calgary; Nuffield Department of Clinical Neurosciences, University of Oxford, UK 


\section{Neurology}

\section{Mystery Case: A 64-year-old woman with subacute encephalopathy \\ Salman Bhai, Alessandro Biffi, Khamidulla Bakhadirov, et al. \\ Neurology 2015;85;e64-e65 \\ DOI 10.1212/WNL.0000000000001868}

This information is current as of August 24, 2015

\section{Updated Information \& Services}

\section{References}

Subspecialty Collections

Permissions \& Licensing

Reprints including high resolution figures, can be found at: http://n.neurology.org/content/85/8/e64.full

This article cites 4 articles, 2 of which you can access for free at: http://n.neurology.org/content/85/8/e64.full\#ref-list-1

This article, along with others on similar topics, appears in the following collection(s):

All Cognitive Disorders/Dementia

http://n.neurology.org/cgi/collection/all_cognitive_disorders_dementia All Infections

http://n.neurology.org/cgi/collection/all_infections

Bacterial infections

http://n.neurology.org/cgi/collection/bacterial_infections

Encephalitis

http://n.neurology.org/cgi/collection/encephalitis

Information about reproducing this article in parts (figures,tables) or in its entirety can be found online at:

http://www.neurology.org/about/about_the_journal\#permissions

Information about ordering reprints can be found online:

http://n.neurology.org/subscribers/advertise

Neurology ${ }^{\circledR}$ is the official journal of the American Academy of Neurology. Published continuously since 1951, it is now a weekly with 48 issues per year. Copyright @ 2015 American Academy of Neurology. All rights reserved. Print ISSN: 0028-3878. Online ISSN: 1526-632X.

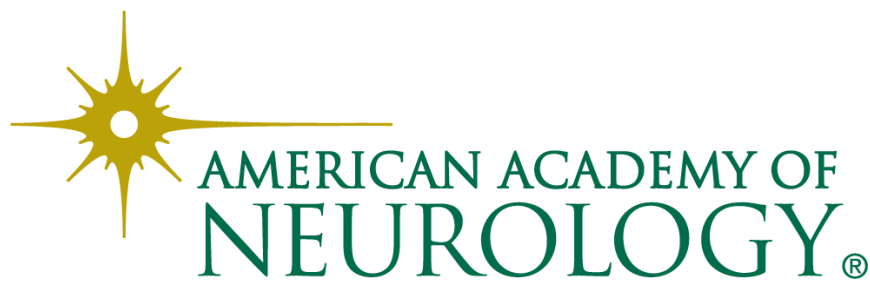

